\title{
Correlation of High Pressure Density Behaviors for Fluid Mixtures Made of Carbon Dioxide with Ethyl Acetate, 1-Propanol, 2-Propanol, or Methanol at $313.15 \mathrm{~K}$ \\ $313.15 \mathrm{~K}$ における二酸化炭素と酢酸エチル、 1-プロパノール、2-プロパノール、あるいはメタノール からなる流体混合物の高圧密度挙動の相関
}

Masahiro Kato*, Takeshi Ono, Koki Sugiyama, and Daisuke Kodama 加藤昌弘*、小野 剛、杉山光紀、児玉大輔

High pressure density behaviors for fluid mixtures made of carbon dioxide with ethyl acetate, 1-propanol, 2-propanol, or methanol at $313.15 \mathrm{~K}$ were satisfactorily correlated. The standard deviation was between 0.12 and $0.30 \mathrm{~kg} \cdot \mathrm{m}^{-3}$ in density for each system.

[Keywords: density, correlation, equation, high pressure, mixture]

$313.15 \mathrm{~K}$ における二酸化炭素と酶酸エチル、1-プロパノール、2-プロパノール、あるいはメタノー ルなる流体混合物の高圧密度挙動を満足できる精度で相関した。相関した密度のそれぞれの標準偏差 は $0.12 \sim 0.30 \mathrm{~kg} \cdot \mathrm{m}^{-3}$ であった。

\section{INTRODUCTION}

The supercritical fluid extraction is now attractive in separation processes. Carbon dioxide is the most popular component as a supercritical fluid. The fluid behaviors of mixtures made of supercritical carbon dioxide with solvent are therefore required in the design and operation of supercritical extraction processes. Ethyl acetate, 1-propanol, 2-propanol, and methanol are typical worthy solvents in chemical industry. The authors[1-4] therefore measured the high pressure density behaviors for fluid mixtures made of supercritical carbon dioxide with those solvents. In the present study, an equation for the correlation of density behaviors of fluid mixtures at high pressures is presented, modifying the Tait equation. With the present density equation, the high pressure density data previously reported by the authors for four binary mixtures made of supercritical carbon dioxide with solvent, ethyl acetate, 1-propanol,

* To whom correspondence should be addressed.

Department of Materials Chemistry and Engineering, College of Engineering, Nihon University, Koriyama, Fukushima 963-8642, Japan.

FAX: (81)-24-956-8862 E-mail: mkatoh@chem.ce.nihon-u.ac.jp 日本大学工学部物質化学工学科、T963-8642 郡山市田村町徳 定字中河原 1 . 2-propanol, or methanol, at $313.15 \mathrm{~K}$ were successfully correlated.

\section{EXPERIMENTAL DATA}

The experimental density data at high pressures were obtained with the variable volume apparatus equipped with the vibrating tube densimeters. The apparatus is the same as that described previously[1-4]. The maximum operating temperature and pressure of the apparatus are $400 \mathrm{~K}$ and $20 \mathrm{MPa}$, respectively. The main parts of the apparatus are a variable volume cell, piston, Ruska 2465-752 and Ruska 2470-703 air lubricated dead weight gauge, Ruska 2480-700 oil dead weight gauge, hand pump syringe, Anton Paar DMA $512 \mathrm{P}$ vibrating tube densimeters, circulation pumps, gas reservoir, and Ruska 2439-702 pressure transducers. The experimental apparatus was sealed with the polytetrafluoroethylene(PTFE) packing. The vibrating tube densimeters were calibrated by dry air and pure water at the experimental temperature.

The apparatus is housed in a constant temperature liquid bath controlled to a temperature to about $\pm 0.01 \mathrm{~K}$. Temperatures were measured with the Hewlett Packard 2804A quartz thermometer calibrated by the triple point of water. The volume of the lower portion of the cell 
could be varied between 234 and $299 \mathrm{~cm}^{3}$ by moving a piston, which gave a volume uncertainty of $\pm 0.01 \mathrm{~cm}^{3}$. First, the cell is evacuated and then filled with carbon dioxide. The pressure difference between the upper and lower spaces is kept close to zero, to minimize the leakage between the upper and lower rooms in the cell. The volume is determined by the motion of the piston. The amount of carbon dioxide is determined from the volume and density.

The solvent was first degassed by the ultrasonic generator in vacuum about 15 minutes. The volume of solvent is then charged into the cell with the syringe pump with an uncertainty $\pm 0.01 \mathrm{~cm}^{3}$. After

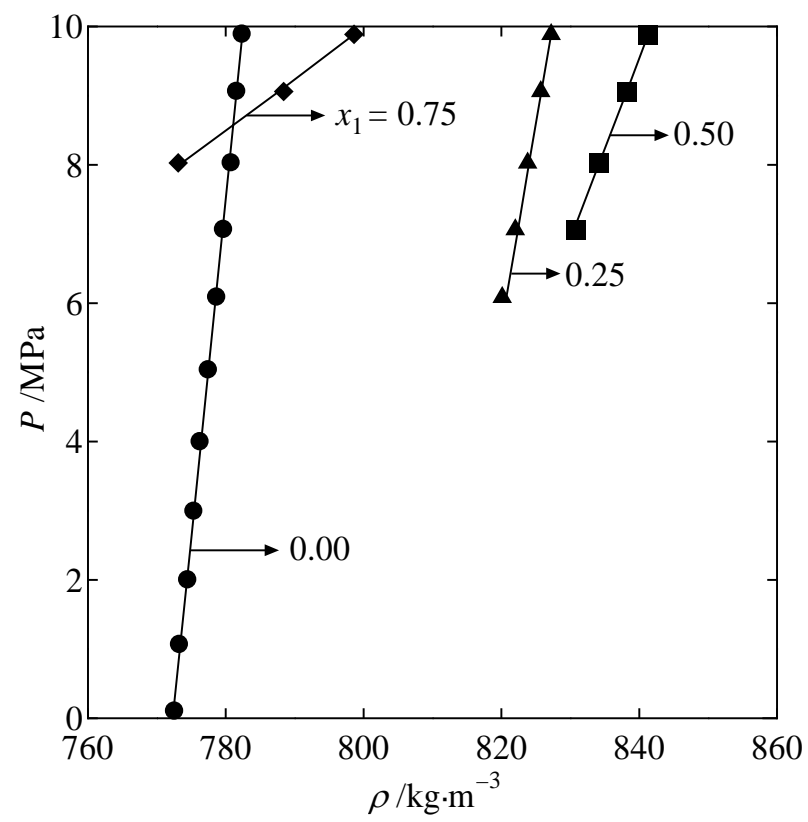

Fig. 1 Volumetric property for carbon dioxide - methanol at $313.15 \mathrm{~K}$ :

○: $x_{1}=0.00, \mathbf{\Delta}: 0.25, \mathbf{\square}: 0.50, \diamond: 0.75$; : equation (1) pressurizing the syringe pump, the solvent is injected into the cell as quickly as possible, to eliminate the dissolution effect of carbon dioxide into the solvent in the syringe pump. The amount of solvent can be determined by the volume and density. The composition of the mixture was evaluated by the amount of carbon dioxide and the one of the solvent injected into the cell.

As the volume of cell is changed, the volumetric properties of the mixture can be measured at a fixed and known composition.

The reliability of the experimental procedures had been confirmed by the agreement between the

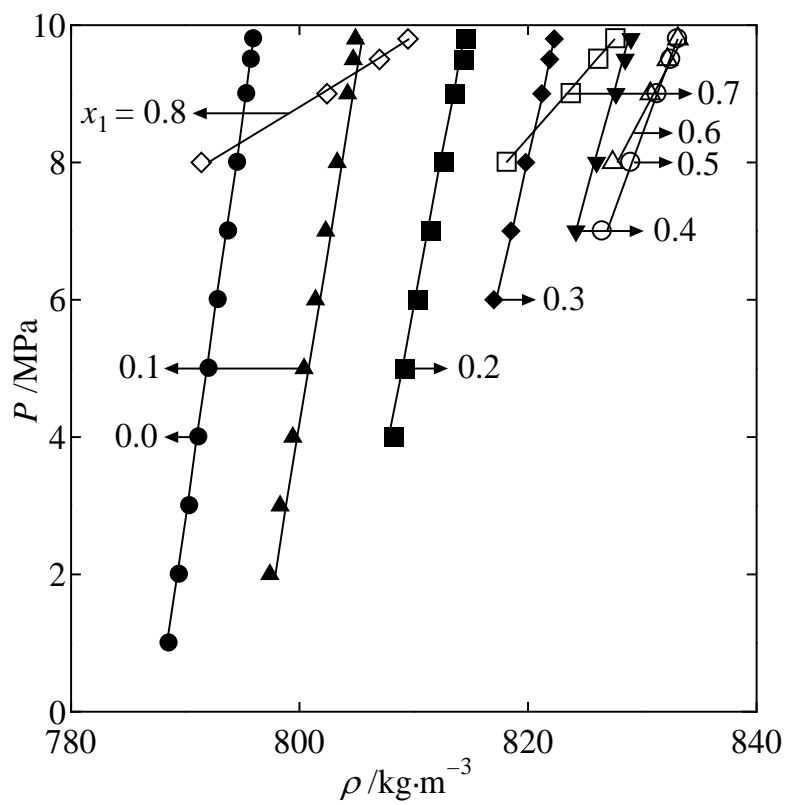

Fig. 2 Volumetric property for carbon dioxide - 1-propanol at $313.15 \mathrm{~K}$ :

О: $x_{1}=0.0, \mathbf{\Delta}: 0.1, \mathbf{\square}: 0.2, \diamond: 0.3, \boldsymbol{\nabla}: 0.4$, ○: $0.5, \triangle: 0.6, \square: 0.7, \diamond: 0.8$; : equation (1)

Table 1 Parameters in density equation (1) for fluid mixtures at $313.15 \mathrm{~K}$

\begin{tabular}{lllllllllllll}
\hline System & $N$ & $\rho_{2}^{0^{*}}$ & \multicolumn{1}{c}{$P^{*}$} & $m$ & $a$ & $b$ & $c$ & $k$ & $A$ & $B$ & $C$ & $\sigma$ \\
\hline (I) & 67 & 885.9 & 10.000 & 40.63 & -1.340 & -1.332 & 0.406 & 0.1067 & 3.042 & 0.962 & 1.109 & 0.12 \\
(II) & 57 & 796.0 & 9.800 & 96.67 & -1.188 & -1.012 & 0.142 & 0.2190 & 4.172 & 1.306 & 1.105 & 0.30 \\
(III) & 60 & 776.9 & 9.800 & 93.05 & -1.166 & -0.910 & 0 & 0.3548 & 4.992 & 2.093 & 1.292 & 0.15 \\
(IV) & 23 & 782.4 & 9.887 & 221.8 & -1.263 & -0.613 & 0 & 0.2734 & 4.783 & 2.009 & 1.139 & 0.27 \\
\hline
\end{tabular}

$\sigma:$ standard deviation, $\sigma=\sqrt{\frac{\sum\left(\rho_{\text {calc }}-\rho_{\text {expl }}\right)^{2}}{N-1}}\left[\mathrm{~kg} \cdot \mathrm{m}^{-3}\right]$

$N$ : Number of data points, $\rho_{2}^{0^{*}}$ : density of solvent at reference pressure $\left[\mathrm{kg} \cdot \mathrm{m}^{-3}\right], P^{*}$ : reference pressure[MPa]

System (I): $\mathrm{CO}_{2}$-ethyl acetate[1], (II): $\mathrm{CO}_{2}$-1-propanol[2], (III): $\mathrm{CO}_{2}$-2-propanol[3], (IV): $\mathrm{CO}_{2}$-methanol[4] 
synthetic bubble point pressure measurements with the present apparatus and the analytical vapor-liquid equilibrium measurements in the separate conventional apparatus[4,5].

The high pressure density behaviors for fluid mixtures made of carbon dioxide with ethyl acetate, 1-propanol, 2-propanol, or methanol at $313.15 \mathrm{~K}$ were measured by the authors[1-4]. No literature values exist for those systems, except ethyl acetate system given by Smith et al.[6]. For carbon dioxide-ethyl acetate, the density data reported by Smith et al.[6] deviated $0.8 \mathrm{~kg} \cdot \mathrm{m}^{-3}$ from the experimental ones reported by the authors[1].

The experimental uncertainties of the pressure, density, temperature and composition are $0.001 \mathrm{MPa}, 0.1 \mathrm{~kg} \cdot \mathrm{m}^{-3}$, $0.01 \mathrm{~K}$, and 0.001 mole fraction, respectively. Carbon dioxide is given with the guarantee better than $99.9 \mathrm{~mol} \%$. The purities of solvents, ethyl acetate, 1-propanol, 2-propanol, and methanol are 99.9, 99.8, 99.9, and 99.9 mol\% in gas chromatograph peak areas, respectively.

\section{CORRELATION}

The high pressure density data[1-4] of the four fluid mixtures made of carbon dioxide with ethyl acetate, 1-propanol, 2-propanol, or methanol at $313.15 \mathrm{~K}$ have been correlated by the following density equation (1).

$$
\rho=\frac{\rho_{2}^{0^{*}}+m x_{1} \frac{1+a x_{1}}{1+b x_{1}+c x_{1}^{2}}}{1-k \ln \left\{1-\frac{1-\left(P / P^{*}\right)}{1+\exp \left[A-B /\left(C-x_{1}\right)\right]}\right\}}
$$

where, $\rho, x_{1}$, and $P$ are density, mole fraction of carbon dioxide, and pressure, respectively. The superscripts, 0 and $\infty$, denote pure and reference, respectively. $P^{*}$ means the reference pressure at high pressure. The subscripts, 1 and 2, denote carbon dioxide and solvent, respectively. Equation (1) has eight parameters, $a, b, c$, $A, B, C, k$, and $m$. Those parameters are independent on composition.

Equation (1) was obtained by the modification of the following Tait equation[6,7] for liquid density at high pressures.

$$
\rho=\rho^{\text {ref }}\left\{1-\alpha \ln \frac{\beta+P}{\beta+P^{\text {ref }}}\right\}
$$

where $\rho^{\text {ref }}$ and $P^{\text {ref }}$ are the reference density and pressure and $\alpha$ and $\beta$ are fitting parameters.

Smith et al.[6] correlated their volumetric density data for supercritical carbon dioxide-ester mixtures with the Tait equation (2) for each composition. The reference density $\rho^{\text {ref }}$ and the parameters, $\alpha$ and $\beta$, depend on composition[6].

The authors[1] previously correlated the density data for carbon dioxide-ethyl acetate by the nine parameter density equation. The parameters were evaluated by giving selected individual points, not with the optimization.

In the present study, the previous density equation was simplified to reduce the number of parameters from nine to eight, as shown in equation (1). The eight parameters are obtained by the optimization. The four parameters in equation (1), $a, b, c$, and $m$, were first obtained by the optimization of the Marquardt method to minimize the sum of the square of the difference of calculated density and experimental density at the highest reference pressure $P^{*}$. Next, the remaining four parameters in equation (1), $A, B, C$, and $k$, were obtained by the optimization of the Marquardt method to minimize the sum of the square of the difference between the calculated density and experimental one in the composition range of the mole fraction of carbon dioxide from 0.0 to 0.8 . Over 0.8 mole fraction of carbon dioxide, the density behaviors seem more close to vapor and far from liquid.

The parameters in equation (1) and the average deviations are shown in Table 1, giving fine results as the standard deviations between 0.12 and $0.30 \mathrm{~kg} \cdot \mathrm{m}^{-3}$ in density.

Figure 1 shows the density behaviors of carbon dioxide-methanol system at $313.15 \mathrm{~K}$, giving excellent performance of equation (1) for density. The points and continuing lines denote the experimental values and calculated ones, respectively.

Figures 2 and 3 give the density behaviors of carbon dioxide-1-propanol system at $313.15 \mathrm{~K}$, with high performance of equation (1) for the density calculation. The points and continuing lines denote the experimental values and calculated ones, respectively. As shown in Figure 3, the convex curves were observed with the maximum points near 0.6 mole fraction of carbon dioxide.

The partial molar volumes of carbon dioxide and solvent were calculated as follows: 


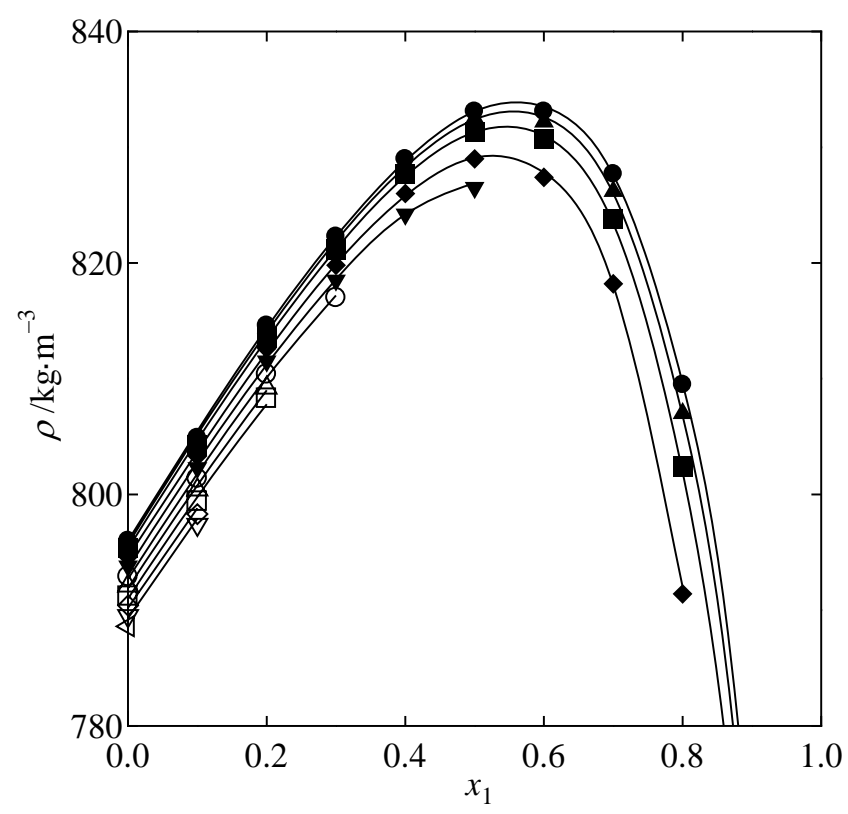

Fig. 3 Experimental and correlated densities for carbon dioxide - 1-propanol at $313.15 \mathrm{~K}$ :

: $9.800 \mathrm{MPa}, \boldsymbol{\Delta}:$ : $.500 \mathrm{MPa}, \boldsymbol{\square}: 9.000 \mathrm{MPa}$,

४ : 8.000 MPa, $\nabla: 7.000 \mathrm{MPa}$, О: $6.000 \mathrm{MPa}$, $\triangle: 5.000 \mathrm{MPa}, \square: 4.000 \mathrm{MPa}, \diamond: 3.000 \mathrm{MPa}$, $\nabla: 2.000 \mathrm{MPa}, \triangleleft: 1.000 \mathrm{MPa}$; : equation (1)

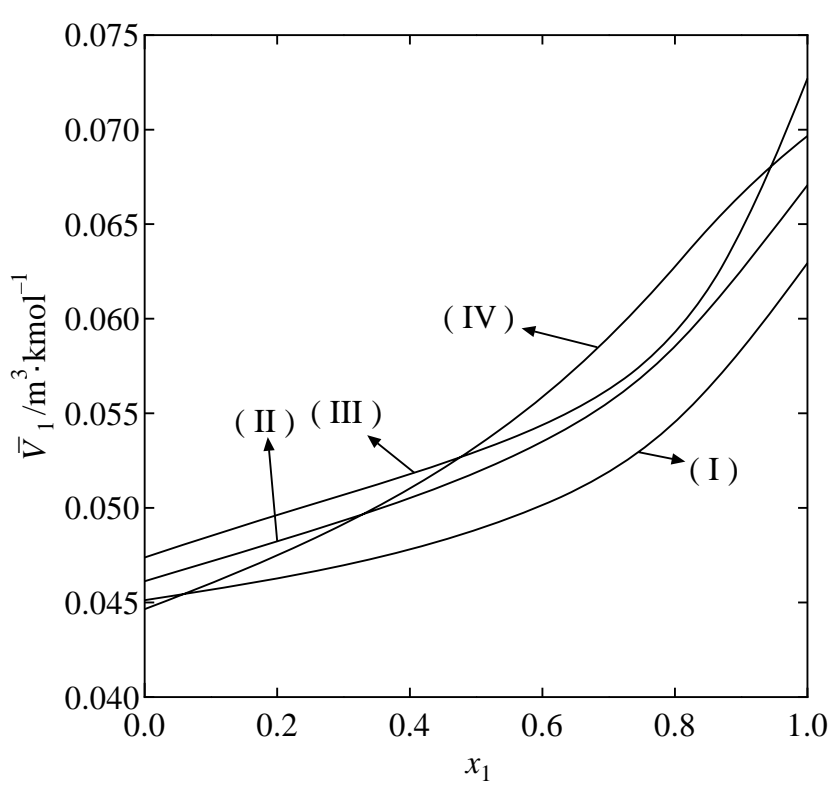

Fig. 4 Partial molar volume of carbon dioxide in fluid mixtures at high pressures $P^{*}$

(I) : $\mathrm{CO}_{2}$-ethyl acetate at $313.15 \mathrm{~K}$ and $10.000 \mathrm{MPa}$

(II) : $\mathrm{CO}_{2}$-1-propanol at $313.15 \mathrm{~K}$ and $9.800 \mathrm{MPa}$

(III) : $\mathrm{CO}_{2}$-2-propanol at $313.15 \mathrm{~K}$ and $9.800 \mathrm{MPa}$

(IV): $\mathrm{CO}_{2}$-methanol at $313.15 \mathrm{~K}$ and $9.887 \mathrm{MPa}$

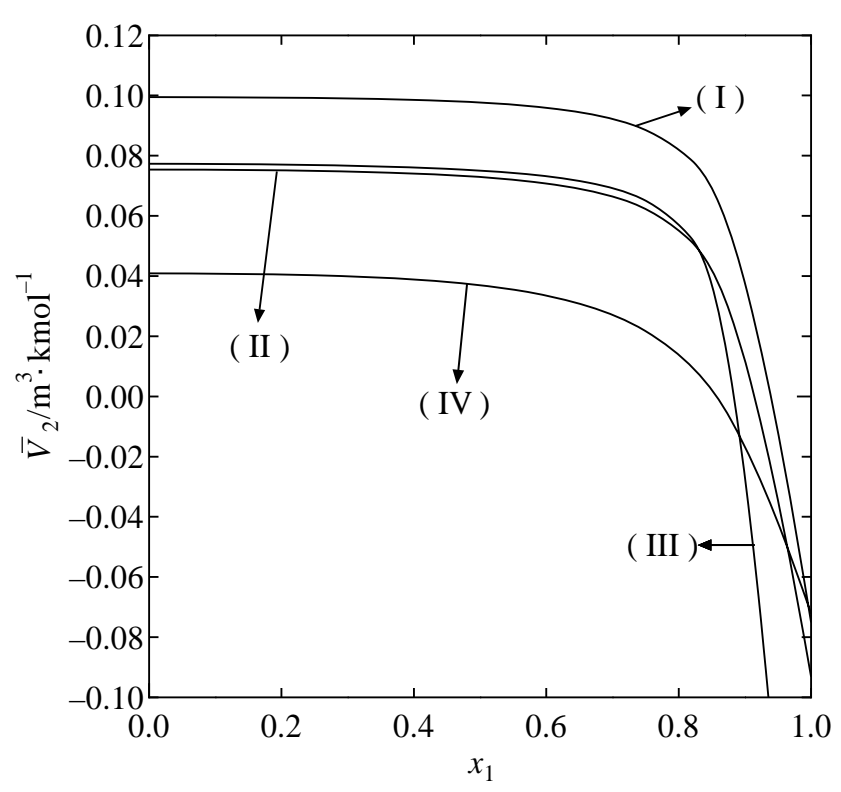

Fig. 5 Partial molar volume of solvents in fluid mixtures at high pressures $P^{*}$

(I) : $\mathrm{CO}_{2}$-ethyl acetate at $313.15 \mathrm{~K}$ and $10.000 \mathrm{MPa}$

(II) : $\mathrm{CO}_{2}$-1-propanol at $313.15 \mathrm{~K}$ and $9.800 \mathrm{MPa}$

(III) : $\mathrm{CO}_{2}$-2-propanol at $313.15 \mathrm{~K}$ and $9.800 \mathrm{MPa}$

(IV): $\mathrm{CO}_{2}$-methanol at $313.15 \mathrm{~K}$ and $9.887 \mathrm{MPa}$

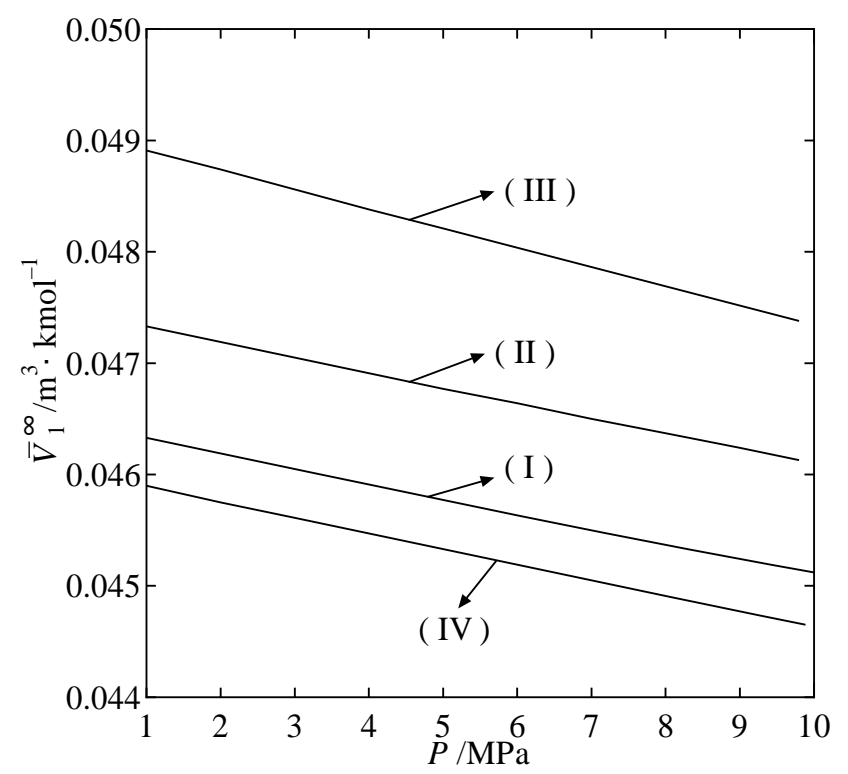

Fig. 6 Partial molar volume of carbon dioxide at infinite dilution in fluid mixtures

(I) : $\mathrm{CO}_{2}$-ethyl acetate at $313.15 \mathrm{~K}$

(II) : $\mathrm{CO}_{2}$-1-propanol at $313.15 \mathrm{~K}$

(III) : $\mathrm{CO}_{2}$-2-propanol at $313.15 \mathrm{~K}$

(IV): $\mathrm{CO}_{2}$-methanol at $313.15 \mathrm{~K}$ 


$$
\begin{aligned}
& \overline{V_{1}}=V+x_{2}\left(\frac{d V}{d x_{1}}\right) \\
& \overline{V_{2}}=V-x_{1}\left(\frac{d V}{d x_{1}}\right)
\end{aligned}
$$

where

$$
\begin{aligned}
& V=\frac{M}{\rho} \\
& M=x_{1} M_{1}+x_{2} M_{2}
\end{aligned}
$$

in which, $V, \bar{V}, M, x$, and $\rho$ denote the molar volume, partial molar volume, molecular weight, mole fraction, and density, respectively. The subscripts, 1 and 2, denote carbon dioxide and solvent, respectively. In the calculation, equation (1) was applied for the density $\rho$.

Figures 4 and 5 show the partial molar volume of carbon dioxide and each solvent at the reference pressure $P^{*}$, respectively. As shown in Figure 4, the partial molar volume of carbon dioxide grew large, increasing the composition of carbon dioxide. As shown in Figure 5, the partial molar volume of solvent sharply fell in the high composition range of carbon dioxide.

Applying equation (1), the partial molar volume of carbon dioxide at infinite dilution $\bar{V}_{1}^{\infty}$ was calculated as follows:

$$
\bar{V}_{1}^{\infty}=V_{2}^{0}+\left(\frac{d V}{d x_{1}}\right)_{x_{1}=0}
$$

where $V_{2}^{0}$ represents the molar volume of pure solvent at given pressure.

Figure 6 shows the partial molar volume of carbon dioxide at infinite dilution, giving the linear relation with pressure.

\section{CONCLUSIONS}

An equation for the correlation of high pressure density behaviors of fluid mixtures made of carbon dioxide with ethyl acetate, 1-propanol, 2-propanol, or methanol at $313.15 \mathrm{~K}$ was presented with the standard deviations between 0.12 and $0.30 \mathrm{~kg} \cdot \mathrm{m}^{-3}$ in density.

\section{NOMENCLATURE}

$A, B, C \quad$ : composition independent parameters in equation (1)

$a, b, c \quad$ : composition independent parameters in equation (1)

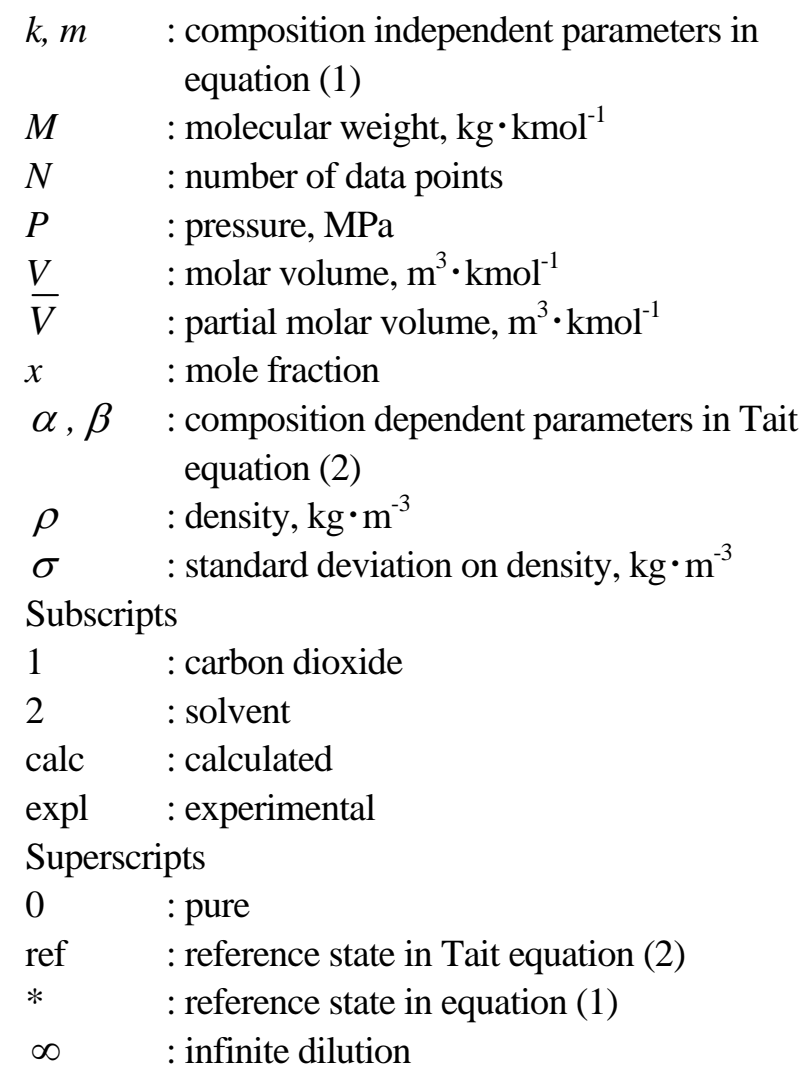

\section{ACKNOWLEDGEMENTS}

The authors thank Mr. Masami Sato and Miss Saori Imamura for their help in the present study.

\section{REFERENCES}

[1] M. Kato, D. Kodama, M. Sato, K. Sugiyama; J. Chem. Eng. Data, 51(2006), 1031-1034.

[2] R. Yaginuma, T. Nakajima, H. Tanaka, M. Kato; Fluid Phase Equilibria, 144(1998), 203-210.

[3] R. Yaginuma, T. Nakajima, H. Tanaka, M. Kato; J. Chem. Eng. Data, 42(1997), 814-816.

[4] D. Kodama, N. Kubota, Y. Yamaki, H. Tanaka, M. Kato; Netsu Bussei, 10(1996), 16-20.

[5] D. Kodama, J. Miyazaki, M. Kato, T. Sako; Fluid Phase Equilibria, 219(2004), 19-23.

[6] R.L. Smith, Jr., T. Yamaguchi, T. Sato, H. Suzuki, K. Arai; J. Supercrit. Fluids, 13(1998), 29-36.

[7] R.E. Gibson, O.H. Loeffler; J. Am. Chem. Soc., 61(1939), 2515-2522.

[Received Nov. 27, 2006, Accepted Feb. 2, 2007] 